\title{
Indigenous Peoples and Gender Roles: The Changing Traditional Roles of Women of the Kalanguya Tribe in Capintalan, Carranglan in the Philippines
}

\author{
Yolanda I. Camaya ${ }^{1}$, Guillume L. Tamayo ${ }^{2}$ \\ ${ }^{1}$ Department of Public Administration, Nueva Ecija University of Science and Technology, Cabanatuan, Philippines \\ ${ }^{2} 7$ th Infantry Division Philippine Army, Palayan, Philippines \\ Email: gabrielarneil77@gmail.com
}

How to cite this paper: Camaya, Y.I. and Tamayo, G.L. (2018) Indigenous Peoples and Gender Roles: The Changing Traditional Roles of Women of the Kalanguya Tribe in Capintalan, Carranglan in the Philippines. Open Journal of Social Sciences, 6, 80-94.

https://doi.org/10.4236/jss.2018.62008

Received: January 17, 2018

Accepted: February 10, 2018

Published: February 13, 2018

Copyright $\odot 2018$ by authors and Scientific Research Publishing Inc. This work is licensed under the Creative Commons Attribution International License (CC BY 4.0).

http://creativecommons.org/licenses/by/4.0/

\begin{abstract}
Part of the uniqueness of Indigenous Peoples is their rich culture and traditions which they have passed down from generation to generation. Focusing on the Indigenous Women of the Kalanguya Tribe in Capintalan, Carranglan, the study endeavors to learn and chronicle the traditional role of the Kalanguya women, how it has evolved through the years, and the factors that caused change. It compares the past and present roles of the Kalanguya women and delves into reasons why acculturation has taken place and why a radical shift in perspective has become evident not only in the Kalanguya women's way of thinking but also in their way of life.
\end{abstract}

\section{Keywords}

Indigenous Peoples, Traditional Roles, Gender Roles, Acculturation, Social Change, Adaptation, Paradigm Shift

\section{Introduction}

The Philippines is home to a large number of indigenous tribes. According to the United Nations Development Program (UNDP), some 300 million indigenous people inhabit large areas of the world, spread across the continents. Indigenous in general, is defined as native to a geographic area where they are found.

The Philippines is a culturally diverse country and has an estimate of $14-17$ million Indigenous Peoples (IPs) belonging to 110 ethno-linguistic groups. A majority of these groups are found in Mindanao (61\%), in Northern Luzon 
(33\%), and a small percentage is left in the Visayas regions. Of the $33 \%$ IPs in Northern Luzon, 6338 indigenous families are based in Nueva Ecija [1].

The United Nations define indigenous communities, peoples and nation as: "Those having a historical continuity with pre-invasion and pre-colonial societies that developed on their territories, consider themselves distinct from other sectors of societies now prevailing in those territories, or parts of them. They form at present non-dominant sectors of society and are determined to preserve, develop, and transmit to future generations their ancestral territories, and their ethnic identity, as the basis of their continued existence as peoples, in accordance with their own cultural patterns, social institutions and legal systems."

Interestingly, the Philippines is the only country in Asia that has officially used the term indigenous peoples and granted full recognition of their rights as embodied in the indigenous Peoples Rights Act (IPRA) of 1997.

The Philippines, being a member of the United Nations, follows a similar definition on the indigenous peoples which according to Paragraph 8, Section 3, and Chapter 2 of IPRA refer to as: "A group or homogenous societies identified by self-ascription and ascription by others, who have continuously lived as organized community on communally bounded and defined territory, and who have under claims of ownership since time immemorial, occupied, possessed and utilized such territories, sharing common bonds of language, customs, traditions and other distinctive cultural traits or who have through resistance to political, social and cultural inroads of colonization, historically differentiated from the majority of Filipinos. Indigenous Cultural Communities/Indigenous Peoples likewise include peoples who are regarded as indigenous on account of their descent from the populations which inhabited the country, at the time of conquest or colonization, or at the time of inroads of non-indigenous religions or cultures, or the establishment of present state boundaries, who retain some or all of their social, economic, cultural and political institutions, but who may have been displaced from their traditional domains."

More than just a piece of art appreciated for their culture and traditions, it has to be understood that indigenous peoples or tribal communities are complex human communities that follow their own tribal rules and structure. And these communities have long standing traditions, with their members playing specific roles that have kept them together through the changing times. Indigenous minority ideologies, cultures, and priorities often contrast that of modern mainstream society, adding further complexity to the already challenging human rights and equity concerns [2].

UNDP asserts that IPs cannot survive or exercise their fundamental human rights without the ability to conserve, revive, develop and teach the wisdom they have inherited from their ancestors. Although some communities have been relatively successful, in most parts of the world, IPs are actively seeking recognition of their identities and ways of life.

The Spanish colonizers introduced many patriarchal cultural values and prac- 
tices [3]. All throughout the colonial decades, the culture of patriarchy had been at work in all aspects in the lives of Filipinos, made evident on how during those times; women were not accorded leadership roles nor were given choice to govern their own lives. Through the church, patriarchy was built into the structures of society; in the consciousness of men and women; integrated into the value system, world view, and socialization process; and reproduced in the family, school, in media, and in the laws [4]. The long history of colonialism has embedded a patriarchal culture among Filipinos. It is noteworthy to see if the Indigenous women of Kalanguya carry traces of this history, or have they survived the era of colonialism and retained their culture but are slowly being drawn to the lure of modern society.

Kalanguyans are ecosystem people with traditional practices that contribute to the protection and preservation of the environment and forest resources [5]. They have their own traits, rituals and beliefs [6] which are manifested on their living traditions and performances, which must be preserved and passed on from one generation to another [7].

The study has four main parts the first part is a documentation of the traditional roles of Kalanguya women based on the description derived from the old members of the community. The second and third parts provide a description and analysis of the present roles of Kalanguya women as they are compared to the traditional gender roles. The last part is a discussion of the change agents that brought about changes in the gender roles of Kalanguya women and its impact to the present Indigenous Communities.

\subsection{Theoretical Framework}

To explain the changes that have taken place within the Kalanguya community, the concept of acculturation, in a chapter in the book Acculturation Advances in Theory, Measurement, and Applied Research was used in the analysis of data [8]. It acknowledges the definition of Berry (1980) of acculturation that involves intergroup contact, conflict, and adaptation; maintaining that "acculturation may be treated as a two-level phenomenon involving the group and the individual." An elaboration of the definition led to the development of an ecological-cultural-behavioral model that attempts to show how behavior varies as a function of eco-cultural settings. The primary interest involves a shift in behavior. In this context, acculturation is considered a multidimensional process generating several definitive outcomes.

\subsection{Objectives of the Study}

The study focuses on the task of recording the traditional roles of the Kalanguya women in Capintalan, Carranglan; it will document and analyze the changes that have taken placed in their traditional roles, and the factors underlying it.

Specifically, the study aims to:

1) to document the traditional roles of the Kalanguya Women in Capintalan; 
2) determine the role that Kalanguya women play within their tribe at present time;

3) compare the differences of Kalanguya women's traditional roles to the evolving role now of the Kalanguya women in Capintalan; and

4) determine what brought about the changes in Kalanguya women's traditional roles and its impact to their tribe.

\section{Methodology}

The study used a qualitative method. The researcher used interview as a means to gather data from the participants. The phenomenological method was also used to identify and analyze the trends that gave rise to the thematic phenomena which later on considered as the merging concepts related to gender roles and the changes that have taken placed. Personal observations were also used to triangulate data taken from personal interview. The results of the interview were further analyzed alongside the prevailing knowledge and results of researches done in the area of gender roles and changes. After triangulation of data and proceeds of personal interview, the emerging concept that brought about changes were discussed and impact to the indigenous community was analyzed.

The tools for the collection of data used are informal, tape-recorded interviews and observation. These tools are used to allow elders to naturally reminisce their youth and vividly recall the traditional activities they did and the chores relegated to them while growing up. No questionnaires were given out but all interviews used the same sets of questions and were recorded with permission from all participants

Purposive sampling method was also used to determine the number of women to be interviewed.

\section{Respondents and Setting}

The concentration of Kalanguya communities can be found in the heart of Northern Luzon's mountainous regions. The government has declared most of these mountain areas either as forest reserves, watersheds or National Parks. The Kalanguya area spans the administrative regions of Pangasinan, Cagayan Valley, Nueva Ecija and the Cordillera.1

The focus of the study is the women of the Kalanguya Tribe living in Capintalan, Carranglan, Nueva Ecija, where the biggest number of Kalanguya families in Nueva Ecija resides.

A total of 22 women were interviewed, which represents young girls, adult women and senior females of the tribe. The respondents were chosen based on their age and educational background (or lack of), willingness to be interviewed, knowledge of tradition, and awareness of the developments taking place within their community.

A permit from the National Commission on Indigenous Peoples was secured to conduct the interview, in compliance to NCIP Administrative Order No. 3, 
Series of 2012.

Carranglan belongs to the Second District of the province of Nueva Ecija. It covers mostly the mountainous area of the municipality and serves as the provincial boundary between Nueva Ecija and the province of Nueva Vizcaya in Region II on the northern side, and the province of Pangasinan in Region I on the southwestern side.

Unlike other Kalanguya communities which are accessible only via foot trails in rugged terrain, the Kalanguya community in Capintalan, Carranglan is traversed by the national road called Maharlika Highway which connects the National Capital Region to the northern regions of the Philippines [9].

\section{Results and Discussion}

According to history, the Kalanguya Tribe originated from the Ifugao hinterlands. There are various stories of how and why the Kalanguyans were able to settle at Nueva Ecija, but each story meets with several disagreements as to its original version.

Cayat (2002) claims that the ancestors of today's Kalanguya people originated in the adjacent communities of Ahin, Taboy, Tucucan and Tinoc (also Tinec). A majority of the Kalanguya people have moved from Ifugao, though most oral tradition affirms that their ancestors originated there.

According to these oral traditions, ancestors of today's Kalanguya migrated due to pressures of warring enemies, known as bohol or bungkillaw/bungkellew (literally, "plague") during a period of headhunting (ngayew). To avoid warfare some sought refuge in the mountains and settled there. Some went to places in what are currently now known as Pangasinan, Benguet, Nueva Ecija and Nueva Vizcaya provinces.

\subsection{Traditional Roles of the Kalanguya Women}

\subsubsection{Traditional Roles: Daily Chores}

Traditional roles of Kalanguya women are shown in Table 1. The responses of Kalanguya women significantly showed the way they lived several decades ago and the role they played within the tribe.

All of the elderly women interviewed said that as far as they can remember, doing the kaingin with their parents were one of their main tasks. Kaingin is slash-and-burn farming (swidden farming) where trees are cut and burned to make way for temporary fields, with the ashes used as fertilizers.

It is normally the men who do the preparation of a kaingin while women do the planting. Planting and harvesting crops like rice, gallang, ginger, taro and kamote (sweet potato) have been the Kalanguyan's way of life while growing up. They are a very hardworking tribe that does not discriminate between men and women when it comes to work.

If there were plenty of infants, the eldest female child would usually stay at home to take care of the baby, while the parents and other children would go to 
Table 1. Traditional roles of senior Kalanguya women.

\begin{tabular}{|c|c|c|c|c|c|c|}
\hline \multirow{2}{*}{ Questions } & \multicolumn{5}{|c|}{ Answers Per Participant } & \multirow[t]{2}{*}{ Total } \\
\hline & 1 & 2 & 3 & 4 & 5 & \\
\hline \multicolumn{7}{|l|}{ Tasks given while: } \\
\hline Kaingin & 1 & 1 & 1 & 1 & 1 & 5 \\
\hline Planting & 1 & 1 & 1 & 1 & 1 & 5 \\
\hline Harvesting & 1 & 1 & 0 & 1 & 0 & 3 \\
\hline Gathering Firewood & 1 & 0 & 1 & 1 & 1 & 4 \\
\hline Taking care of Children & 1 & 0 & 1 & 0 & 1 & 3 \\
\hline Washing clothes & 1 & 0 & 0 & 0 & 1 & 2 \\
\hline Cooking & 0 & 1 & 0 & 1 & 0 & 2 \\
\hline Raising native animals & 0 & 1 & 1 & 0 & 0 & 2 \\
\hline $\begin{array}{l}\text { Are men's tasks } \\
\text { different from } \\
\text { women's? }\end{array}$ & No & No & No & No & No & 5 \\
\hline $\begin{array}{l}\text { Were there women } \\
\text { leaders? }\end{array}$ & None & None & None & None & None & 5 \\
\hline $\begin{array}{l}\text { Were you allowed to } \\
\text { choose your husband? }\end{array}$ & No & No & No & No & No & 5 \\
\hline $\begin{array}{l}\text { Did you have any } \\
\text { formal education? }\end{array}$ & No & No & No & No & Yes & $\begin{array}{l}\text { No }(4) \\
\text { Yes (1) }\end{array}$ \\
\hline
\end{tabular}

the forest to do kaingin, gather crops, plant or get wood. (Recorded Interview: September 9, 2017, 10:00 a.m.)

Often times, if parents had to go to the field or the forest and no one could take care of the baby, it would come along with them in a sling they call an aban, which is placed across a woman's chest; or the baby is put in a basket called kayabang which is placed on the back and secured by rope tied to the forehead. (Recorded Interview: September 9, 2017, 9:00 a.m.)

According to one of the eldest female in the community, girls as young as six years old were taken along the field or the forest to learn about kaingin and planting. It will be one of their main responsibilities until such time that they marry, bear children, and are given other work to do.

The above interview result was supported by the study of Gabriel and Mangahas (2017) when they said that the Kalanguyans are ecosystem peoples who have sound knowledge and intimate relationship with their environment. They rely on their environment for subsistence and regard it as their life. This largely explains why the whole Kalanguya tribe, and not only the women, spends a majority of their time and lives in the forest, doing kaingin, planting, harvesting and gathering firewood. For the longest time, it was the only way of existence they knew of.

Based on the interview notes gathered, the family of one of the eldest women came from the Igorot tribe in Bengue as a result of the Second World War. They were forced to move down from the mountains when Americans declared the 
mountainous area of Cordillera as "No man's land." To avoid being caught in the cross fire, their family moved to the lowlands of Pangasinan and after two years in the lowlands, the family moved back to Benguet and Magcia Lopez Umalyo, one of the oldest Kalanguya women interviewed, was born. Magcia grew up watching her parents working in the mountains and doing kaingin. She was taught how to do the work of her parents, too. When she reached an appropriate age, she was soon married to another Kalanguya native who knew of Kalanguyans residing in Capintalan, Carranglan, where they eventually ventured off to start their family. Having settled in Capintalan, Magcia returned to the traditional practice of doing kaingin, planting crops, harvesting, and selling her harvest and seeds to those who had money to buy.

Oral histories, such as the one Magcia gave during the interview, cause many to erroneously conclude that the Kalanguya are a sub-group of the Ifugao. However, they are culturally and linguistically distinct from the present-day Ifugaos, another group of Indigenous Peoples [10].

Another interview with an elderly woman of the Kalanguyans revealed that the Kalanguya families of before preferred their children to work alongside them, rather than attend school. One of the reasons stated was because there were no schools near their area. If there were, the priorities for schooling were given to boys and men. With plenty of children in the family, the eldest daughter would take care of her siblings while the boys of schooling age attended school.

\subsubsection{Traditional Roles: Courtship and Marriage}

As shown in Table 1, the senior women of Kalanguyans in Capintalan were not allowed to choose their husbands, they were instead betrothed at an early age or married off to a man their families have chosen. Although this is the result of the actual interview conducted, further research into written histories of Kalanguyans revealed that in courtship and marriage, the Kalanguyans have two traditions: one is the Kinalon and the other, Kaihing.

Kinalon is the usual marriage done through an intermediary (Makalon). In such situation, it is the man who would signify an interest to a woman by approaching one of the nangkaama (male elders), and asking for help to approach the family of the woman. When an agreement has been reached, the timbal (marriage ceremony) will soon follow.

The Kaihing, is basically a betrothal. It is an early negotiation between two families for the marriage of their children. Sometimes it is intended to settle family disputes where the offender and the offended family are required by the nangkaama to settle their feud through kaihing, requiring the offender to betroth his son to the daughter of the offended. Secondly, kaihing is also a voluntary act between two families to strengthen their existing good relationship. There is no minimum age required for this, for even an unborn child could be betrothed.

The nangkaama is highlighted by bringing a bottle of rice wine which will be opened and shared to act as a seal when they think that the woman has agreed and accepted the man. Most of the time, the woman do not literally say yes 
buther actions and gestures like crying or keeping quiet will be interpreted as saying yes. The woman is not expected to say anything during a kalon (proposal), but once she speaks, it is a signal that she is saying "no" to the man who is proposing; however, actual interview revealed that no woman ever dares to speak when a proposal is ongoing, especially when both sides and the elders have shown inclination for a union. During the kalon, the elders will tell the woman all the good qualities of the man proposing.

In a traditional Kalanguyan community, a woman never makes the first move, it is a taboo, for the respectability of a single woman is said to be in her ability to stay pure until a man proposes marriage to her.

\subsubsection{Traditional Roles: Pregnancy and Childbirth}

In pregnancy and childbirth, when a Kalanguya woman is pregnant, the tasks she used to do like kaingin, planting and harvesting, still continue. It is only during the latter part of the pregnancy where the woman avoids carrying heavy loads. Kalanguya women usually give birth alone; sometimes they are assisted by their husbands or a woman neighbor. One interview with a Kalanguya woman even revealed that the women of the tribe have been known to give birth while doing kaingin. The very act of giving birth alone shows how self-sufficient the women of Kalanguya are.

As for the Kalanguya healing practices, the community has a respected maba$k i$ or native priest that performs the ritual of healing. The mabaki is usually a man, this is if we base our findings on available manuscripts of studies done on the Kalanguya tribe; however, according to one of the women elders interviewed, there were times when the mabaki was female. They often performed baki or canao, which is an act of offering the blood of slaughtered native animals to appease the spirits and heal the afflicted person; which partly explains why native pigs and poultry have always been present in Kalanguya communities. If we consider the results of the interview with the women elders of the Kalanguyans, the mabaki would perhaps be the highest traditional position or role that a Kalanguya woman has ever occupied.

The Kalanguya women generally worked side by side with the men, and are responsible for providing food for the family. They plant, weed and harvest in the fields. The men, on the other hand, do the heavier and more irregular work such as gathering wood for fuel and plowing. They are basically peace-loving people, and when it comes to tribal leadership, the women take the role of a submissive follower.

\subsection{The Kalanguya Women of Today}

The Kalanguya women of today include respondents as young as 6-year old girls to women up to the age of 59. Questions asked during the interview for the present day role of the Kalanguya women in Capintalan was translated and put in a table, to better analyze the transition in the role of the Kalanguya women from traditional to a more modern role. Please refer to Table 2 below. 
Table 2. Roles of the Kalanguya women of today.

\begin{tabular}{|c|c|c|c|c|}
\hline \multirow{2}{*}{ Questions } & \multicolumn{4}{|c|}{ Answers by Age Bracket } \\
\hline & $6-12 y / o$ & $13-19 \mathrm{y} / \mathrm{o}$ & $20-39 \mathrm{y} / \mathrm{o}$ & $40-59$ y/o \\
\hline $\begin{array}{l}\text { Are you attending school right } \\
\text { now?/Were you able to } \\
\text { attend formal education? }\end{array}$ & Yes $(4 \mathrm{x})$ & Yes $(4 \mathrm{x})$ & $\begin{array}{c}\text { Yes }(2 \mathrm{x}) \\
\text { Yes, until high } \\
\text { school }(2 \mathrm{x})\end{array}$ & $\begin{array}{l}\text { Yes, with a Degree on Social } \\
\quad \text { Work }(1 \mathrm{x}) \\
\text { Yes, a college undergrad }(1 \mathrm{x}) \\
\text { Yes, until elementary }(3 \mathrm{x})\end{array}$ \\
\hline $\begin{array}{c}\text { Do you think education is } \\
\text { important? }\end{array}$ & Yes $(4 \mathrm{x})$ & Yes $(4 \mathrm{x})$ & Yes $(4 \mathrm{x})$ & Yes $(5 x)$ \\
\hline $\begin{array}{l}\text { Were you taught how to do the } \\
\text { kaingin and plant crops? }\end{array}$ & No $(4 \mathrm{x})$ & No $(4 \mathrm{x})$ & $\begin{array}{l}\text { No }(2 \mathrm{x}) \\
\text { Yes }(2 \mathrm{x})\end{array}$ & Yes $(5 x)$ \\
\hline Are/Were you betrothed? & No $(4 \mathrm{x})$ & No $(4 \mathrm{x})$ & No $(4 \mathrm{x})$ & $\begin{array}{l}\text { Yes }(1) \\
\text { No }(4 \mathrm{x})\end{array}$ \\
\hline $\begin{array}{l}\text { What is/was your main } \\
\text { responsibility in your family? }\end{array}$ & $\begin{array}{c}\text { Study hard } \\
\text { Help in household } \\
\text { chores } \\
\text { Be obedient }\end{array}$ & $\begin{array}{c}\text { Study hard } \\
\text { Help in household } \\
\text { chores } \\
\text { Help in the family } \\
\text { business }\end{array}$ & $\begin{array}{l}\text { Work hard } \\
\text { Help in the fields } \\
\text { Be active and give } \\
\text { back to the } \\
\text { community }\end{array}$ & $\begin{array}{c}\text { Work in the fields } \\
\text { Raise native animals } \\
\text { Work in the Coop } \\
\text { Do household chores } \\
\text { Help in the community, } \\
\text { Participate community activities } \\
\text { and meetings }\end{array}$ \\
\hline $\begin{array}{c}\text { Do women occupy important } \\
\text { positions in your community?/Do } \\
\text { you think women play an important } \\
\text { role in your community? }\end{array}$ & Yes $(4 \mathrm{x})$ & Yes $(4 \mathrm{x})$ & Yes $(4 \mathrm{x})$ & Yes $(5 x)$ \\
\hline
\end{tabular}

Based on the answers in Table 2, it is evident that there has been a shift in the way the Kalanguyans think. Though the older respondents were still taught the old way of subsistence, they have come to realize the importance of education. Furthermore, those under the first two groups having the youngest age bracket (6 - 12 and 13 - 19) are all attending school. For those under the age of 20 - 39, two of the respondents were able to finish a degree in Education. In fact, one is already teaching at the local High School in Capintalan, while the other one is a teacher in Isabela, which is a province further up north. The one that teaches in Isabela is just waiting for an opening to be able to transfer back to Capintalan in hopes of also teaching at the local High School. These educated women do this out of a genuine desire to give back to the Kalanguya community which helped them finish College. They stated that they are proud of their roots and would love to give the Kalanguya youth the opportunity to study.

When the young girls were asked as to what they dream of becoming when they finish their studies, almost all of them resolutely answered that they want to be teachers. Again, with the desire to be of service to the community and to see more of their people educated. They have been raised with the belief that education gives one power to rise above poverty.

For those in the age bracket of 40 - 59 years old, when asked about what future they want for their daughters, they answered that they definitely did not want to see their daughters in the fields nor in the forest doing manual labor. They 
would rather have their daughters study and work to earn properly and have a good life. Moreover, if they themselves were given an opportunity to further their studies, they would have grabbed it to experience a better life, too.

Ironically, if during the old days it was the men who were sent to school to be educated and eventually help the family, today, the younger men of the Kalanguya community would rather do manual labor like plow the fields and do kaingin; this according to the interview with the more mature generation of Kalanguya women who had sons who did not want to go to school. Based on their statements, the boys find it more difficult to cope at school and would rather work, while the girls are motivated to study and break free from the traditional image they often see in their grandmothers who still insist on doing kaingin, planting and harvesting, even if they could afford not to do so anymore.

The most empowering development, perhaps, for the Kalanguya women is the fact that in 1985, the Kalanguya community voted for a woman as their Barangay Captain (who is also among the women interviewed for this study). Though she only reached as far as high school in her education, her passion to serve her people more than made up for what was lacking. For the first time, a position of leadership was given to a woman, which did much to boost the morale of the women in the Kalanguya Tribe. She stayed in position from 1985 to 1994. And it was during this time that more activities for Kalanguya women, leaning towards livelihood trainings, were conceptualized and started.

From an outsider's point of view, the radical change that manifested in the Kalanguya community, with regards to the role of women may appear to be too fast in coming. However, delving into their history through the various interviews conducted would reveal that shift was actually gradual, considering their location and the outside influences that continue to bombard them.

With education finally taking an important place within the Kalanguya community, and with the women taking in more important roles, it is not surprising that they have found their voice and have become more vocal when it comes to choosing the person they are to marry. Perhaps this is one of the most welcome developments, where the Kalanguya women are now free to marry a person of their choice. Tribal intermarriages between other tribes such as Ibalois and Kankana-eys, and even local lowlanders and highlanders are now allowed and accepted.

\subsection{A Comparison of Roles}

Even before World War II, the women of the Kalanguya Tribe have been known as hard workers that labored in the fields doing kaingin, weeding, planting, harvesting and raising native animals. As early as six years old, they have been taught to work. They were betrothed to men not of their choosing, but sometimes they were given an option to refuse. Education was just a word to them and they were not given the opportunity to attend school, mainly due to poverty and the fact that there were no schools near them, for they lived in the moun- 
tains. They were not given positions of leadership, nor were they allowed to sit in councils and decide the fate of their tribesmen. They are a silent, diligent, and peace-loving lot who are submissive to the decisions of the men and their elders.

Today, almost 80 percent the women of the Kalanguya tribe in Capintalan, Carranglan are educated, not including those who belong to the age bracket of 60 years old and above. They seldom go with the men to do kaingin, but in their own backyards they still raise a few native chickens and pigs, and tend to some crops. They still do household chores but are given enough time to study and be with their peers. They now know the value of education and are striving to make something of themselves and give service to their fellow Kalanguyans. They are free to choose the man they want to marry, enjoy the courting process and take equal responsibility in raising a good family. More importantly, they have now been recognized as equally deserving to be given a position of trust and leadership within the Kalanguya community. In a nutshell Table 3 below shows the comparison of roles of the traditional and present day women of Kalanguya Tribe, to wit.

The researcher's first visit to the Kalanguya community in Capintalan was at the Barangay Hall were children were playing at the basketball court fronting the Hall. During that time, an old woman passed by. Approaching the woman and making proper introductions confirmed that the woman was Kalanguyan and could understand the researcher's language. And she was on her way to do kaingin in the forest.

Most of the women were at the United Church of Christ in the Philippines (UCCP). An interview later on would reveal that Catholic and other Christian American missionaries came to teach the word of God to the Kalanguyans, during the mid-70's. Although most of the elders remained loyal to their faith, a majority were convinced that their Kabunyan (the god they worship) is no different from the God that Christians believe in. Since then, Sunday to them became a day of worship, a day of dressing up, and getting together with the community.

The contrast between the old and the new traditions was never more clear and evident than that moment, as an old Kalanguyan woman prepared to go up the mountains to do kaingin, while the children were playing in the barangay hall, and most of the younger women were at church, praying to a God that was not the God of their ancestors.

Table 3. Comparison of roles of Kalanguya women.

\begin{tabular}{lcc}
\hline \multicolumn{1}{c}{ Aspects of Comparison } & Traditional Roles & Present Day Roles \\
\hline 1) Doing Kaingin & Yes & No \\
2) Education & None & Yes (80\% of women) \\
3) Bethrotal & Yes & Yes \\
4) Opportunity for community leadership & None & Yes \\
5) Silence and Submissiveness to & Yes & Not \\
\hline
\end{tabular}




\subsection{Factors Underlying Change}

Change is an enduring fact of human life. No development can ever take place without change. The quest for a better life always starts with change, be it at an individual level or at a group level, such as organizations and communities working together to achieve something better, to seek out alternatives that will improve their quality of life, and organize systems, invent forms of technology that will level up their tools.

Some change is programmed and determined by evolutionary and sociological forces. The remaining portion is acquired through a multitude of circumstantial and socio-cultural influences. The study of acquired and imposed change forms the bulk of research initiatives in the social and behavioral sciences. According to Fisher (1982) "at one level of inquiry, research is centered on social change", or at the "modification or alteration in the social structure of society".

One of the major sources in the development and display of human behavior is the contact between cultural populations. Such intercultural contacts result in both cultural and psychological changes. At the cultural level, collective activities and social institutions become altered, and at the psychological level, there are changes in an individual's daily behavioral repertoire [11]. At the individual level, the changes manifest in how people acculturate and how well they adapt to this process.

Acculturation is a salient form of social change. To account for and draw attention to this dynamic phenomenon, Redfield, Linton, and Herskovits (1936), (cited in [12]) proposed the term acculturation and defined it as a "phenomena which results when groups of individuals having different cultures come into continuous first-hand contact with subsequent changes in the original culture patterns of either or both groups". Acculturation was therefore perceived to be the result of long term contact among individuals of different cultures. In the course of the interaction between the groups, much cultural diffusion, borrowing, and conflict typically occur, often leading to immutable changes in an individual's "life-ways" and "thought ways". The essential concepts are change and adaptation.

In the case of the Kalanguya women in Capintalan, Carranglan, they had to adapt to the changes in their environment, in the climate, in the manner and ways of the different kinds of people they are dealing with and the technology and systems that people from mainstream society introduced to them.

One of the main reasons why the Kalanguyans continued with their old ways of living and their old farming methods was because of their location. They were in the mountains, and the kaingin system was a suitable method for their environment, and the only system they knew of which provided almost all of their basic needs.

Education was not an option for there were no schools nearby, nor was there enough money. According to Gabriel (2017) [13] poverty and lack of access to quality education are among the major reasons why indigenous women have 
lagged behind others in terms of social consciousness.

When the Kalanguyans began to disperse from their original ancestral land and went as far as Pangasinan, Nueva Ecija and Nueva Vizcaya, they were exposed to new surroundings, new beliefs, and new systems.

Kalanguyans who established a community in Carranglan, specifically in Capintalan, which is traversed by the Maharlika Highway, was eventually introduced to Catholicism and Christianism. One interview suggested that it was the Canossian Sisters who first set foot in the Kalanguya community in Capintalan during the late 60s, American missionaries followed, who introduced the UCCP in the 70's. And through them, the Catholic and the UCCP church was established in Capintalan and neighboring barangays. Through the years that followed, several churches were introduced to the Kalanguya community which offered livelihood assistance and other programs to uplift the living conditions of the Kalanguyans.

In the 1990s, with the consensus of the nangkaama, help from local government agencies was welcomed by the Kalanguya community in Capintalan. A public elementary school already existed in a nearby barangay, and the Kalanguya children had free access to elementary education, with most of their needs supported by the NCIP.

By 1996, a local High School was established in the area and the people saw its first batch of Kalanguya High School graduates in the year 2000. From among these graduates, the NCIP selected a few scholars which were enrolled in the course Bachelor of Arts in Education. These scholars were the first Kalanguyan teachers who now teacher at the local High School (and who are also part of the sample population of women interviewed).

In 2001, a women's cooperative was organized in Capintalan, and by 2002, the Samahang Kababaihan ng Capintalan Multi-Purpose Cooperative (MPC) was registered and recognized by the Cooperative Development Authority. A total of 100 women of the Kalanguya community are members of the MPC.

The MPC mainly focused on lending money, seeds and produce for the Kalanguyans, so that they need not resort to loan sharks. It also introduced new crops that are sturdier and could withstand the effects of climate change. Trainings and seminars were conducted to the women of the tribe and lectures on Gender and Development (GAD) were also included.

Based on the interviews conducted, the Kalanguya women think that it is good for them to have knowledge on GAD, specifically on the Violence against Women and Children Act (VAWC), but being the peace-loving and obedient women that they are known for, they do not consider it as one of their major problems. From this point, other cooperatives and programs started to snowball for the Kalanguyans of Capintalan, and of the neighboring barangays in Carranglan where Kalanguyans reside.

With the help of the local Women's Cooperative, Kalanguyans have found a more affordable means of establishing simple businesses that provides extra in- 
come for the family, capacitating and empowering the women to be more and do more.

The establishment of a local High School paved to the way to better education opportunities, and through the help of several agencies, the Kalanguya youth now have access to free college education, though they have to go through a strict selection process.

These are the factors that have gradually changed the traditional roles of the Kalanguya women in Capintalan, from being laborers to becoming educators, entrepreneurs, barangay leaders, social workers and nurses. Or simply be women that can take their place in the society, be heard and make a difference.

Although they continue to retain the values and some of the beliefs taught to them by their ancestors, they nonetheless know that the only way to go would be to move forward, while cherishing, protecting and remembering the roots from where they came from.

\section{Conclusion and Recommendations}

The study showed that the indigenous women of the Kalanguya tribe in Capintalan, Carranglan of Nueva Ecija still recall most of their traditional roles as women of the tribe. Although the advent of modernization has come to their community and they have embraced the changes it has caused, they nonetheless still value their traditions and culture. They are proud of their ancestry and have genuine desire to be educated and give back service to their people.

Since most of them still live and depend on the forest, support mechanisms from the government and non-government organizations for the protection and management of their forest resources should pushed.

The diligence and hard work that the Kalanguya women display, and their good work attitude make them deserving of more government programs that would cater to their needs and bring further development. They should be exposed to more trainings, because they display a wide understanding of concepts and seem to be natural leaders in their own right.

These exposure and trainings will eventually lead to a new and better way of living for the Kalanguyans, so there is an immediate need to document their culture, beliefs and traditions as they may be lost in history. Following the development of the Kalanguya community and chronicling the events and situations that effect change in it should be a work in progress, for an accurate perspective of their history.

\section{References}

[1] National Commission on Indigenous People (2013) Ancestral Domain Development and Protection Plan (ADSPP) of the Kalanguya Tribe in Carranglan. NCIP Office, Cabanatuan.

[2] Balilla, V.S. (2013) Indigenous Aeta Magbukún Self-Identity, Sociopolitical Structures, and Self-Determination at the Local Level in the Philippines. Journal of Anthropology, 2013, Article ID: 391878. https://doi.org/10.1155/2013/391878 
[3] Anonuevo, C.Q. (2000) An Overview of the Gender Situation in the Philippines. Retrieved from Friedrich-Ebert-Stiftung at http://library.fes.de/pdf-files/bueros/philippinen/50069.pdf

[4] Medina, N.A., et al. (2015) The Culture of Patriarchy and Its Effects on the Human Rights of Girl-Children in Cagayan de Oro and Claveria, Misamis Oriental: Implications to Policy Formulation. Discussion Paper Series No. 2015-44. https://dirp3.pids.gov.ph/webportal/CDN/PUBLICATIONS/pidsdps1544_rev.pdf

[5] Gabriel, A. and Mangahas, T. (2017) Indigenous People's Contribution to the Mitigation of Climate Variation, Their Perception, and Organizing Strategy for Sustainable Community Based Forest Resources Management in Caraballo Mountain, Philippines. Open Journal of Ecology, 7, 85-100.

https://doi.org/10.4236/oje.2017.72007

[6] Cayat, G.C. (2015) Manuscript on Kalanguya Cultural Communities.

http://ncca.gov.ph/subcommissions/subcommission-on-cultural-communities-andtradition-

al-arts-sccta/northern-cultural-communities/manuscript-on-kalanguya-cultural-co mmunities/

[7] Arsenio, B. and Stallsmith, G. (2008) Preserving the Living Traditions in Live Performances: A Traditional Music and Dance Troupe of Kalanguya of the Northern Philippines.

http://www.seameo.org/_ld2008/doucments/Presentation_document/Arsenio_Stalls mith.pdf

[8] Trimble, J.E. (1989) Multilinearity of Acculturation: Person-Situation Interactions. In: Keats, D.M., Munro, D. and Mann, L., Eds., Heterogeneity in Cross-Cultural Psychology, Swets \& Zeitlinger, Amsterdam, 173-186.

[9] The Kalanguya Tribe. http://lusodkabayan.weebly.com/the-kalanguya-tribe.html

[10] Peralta, J.T. (2003) In Focus: Ifugao Hudhud: Local to Global Dimension of the Sacred.

http://ncca.gov.ph/about-culture-and-arts/in-focus/ifugao-hudhud-local-to-globaldimension-of-the-sacred/

[11] Sam, D.L. and Berry, J.W. (2010) Acculturation When Individuals and Groups of Different Cultural Backgrounds Meet. http://journals.sagepub.com/doi/abs/10.1177/1745691610373075

[12] Redfield, R., Linton, R. and Herskovits, M. (1936) Memorandum for Acculturation. American Anthropologist, 38, 149-152. https://doi.org/10.1525/aa.1936.38.1.02a00330

[13] Gabriel, A. (2017) Indigenous Women and the Law: The Consciousness of Marginalized Women in the Philippines. Asian Journal of Women Studies, 23, 250-263. https://doi.org/10.1080/12259276.2017.1317705 